\title{
The Roles of Grand-parenting in Mothers' Labor Participation in Indonesia
}

\author{
Analysis of SUPAS 2015
}

\author{
Umar Riyadi \\ Master Program in Population and Labor Economics \\ Faculty of Economics and Business, Universitas Indonesia \\ Depok, Indonesia \\ oem1212@gmail.com
}

\author{
Omas Bulan Samosir \\ Lembaga Demografi \\ Faculty of Economics and Business, Universitas Indonesia \\ Depok, Indonesia \\ omasbr@yahoo.co.uk
}

\begin{abstract}
This study is aimed to investigate the effects of grand-parenting on mother's work participation. The data used came from SUPAS 2015 and were analyzed using a multinomial logistic regression. The unit of analyses is women aged 15-54 years who are in union, live with their husbands or spouses and have children aged 12 years old or younger. The results of this study show that the presence of grandparent in a family gives a positive influence on a mother's chances to work both in formal and informal sectors, even when grandparents are not involved in grand-parenting. The effect is greater when grandparents participate in "momong cucu" (childcare), in the form of grandparenting.
\end{abstract}

Keywords—grand-parenting; childcare; formal-informal sector; labor force; Indonesia

\section{INTRODUCTION}

The diverse types of employment of men and women along with changes in the structure of jobs caused by economic development are not enough to eliminate segregation of work by sex. Worldwide, women are concentrated in lowproductivity jobs, such as in the agricultural sector or run small businesses, and most of them are unpaid workers or engaged in the informal sector. Even if they enter the formal sector, women rarely attain important positions/power [1].

Ref. [1] concluded that in terms of household responsibilities and the utilization of time, women bear a disproportionate share of household and nursing (child and elderly) responsibilities. The prevailing social norms surrounding the roles of women in the households and community also play roles in female labor participation. Thus, when a woman decides to enter the labor market, she will be faced with the emergence of a fixed cost as she leaves or reduces the portion of her responsibilities. Fixed work schedules and minimum hours of work, as well as differences in adjustment of household responsibilities, create barriers for women to be engaged in the labor market, especially in the formal sectors.

Indonesia is no exception. Although Indonesia's Gender Development Index (IPG) is actually quite high (above the world average) and shows an increase every year (2010-2014), it is only targeting the improvement of basic capabilities of
Indonesian women, including health, education, and decent life, and the employment side instead [2]. Only around half of working age women in Indonesia participate in the labor market. This in turn affects the Indonesia's competitiveness compared to other countries as reflected in the Global Competitiveness Index (GCI). GCI illustrates the level of a country's productivity and pictures the level of prosperity that can be achieved through the economy. Indonesia ranks the lowest among ASEAN countries in terms of competitiveness (The Global Competitiveness Report 2015-2016).

Furthermore, [3] in his time allocation theory, stated that the decision to work is determined by the time value between domestic work and the market work; and the time value is determined by the amount of wage. But for women, the choice is not only to work or not to work. The decision to work is also influenced by the choice whether to choose paid work, but away from home so as to be less compatible with child-rearing and housekeeping, or, to choose non-wage work and being a family and unpaid worker, but flexible in time and near home or even at home (King, 1987 in [4]). Similarly, [5] also affirmed that the question of "work or not work" is not relevant when it comes to the participation of the female labor force.

For a mother who has children, childcare arrangement is a key element to be taken in her decision to work, and it is highly dependent on the extent to which women's basic abilities are able to harmonize parenting and participating in the labor market [6]. To that end, grandparents, especially grandmothers, have become common choices in helping child care (in the form of grand-parenting) because of their flexibility and affordability [7]. Parenting by grandparents is seen as a bridge of intergenerational relationships where a large transfer of resources from parents to their offspring takes the form of parenting provided by grandparents [8]; [9]. The transfer of time from the old to the younger generation mainly occurs because 'needs' may come from a variety of factors, including family structure (i.e., single parent) or financial difficulties (i.e., unaffordable private child care). These needs can be mediated by the institutional arrangements in which the parent resides, taking into account the characteristics of the grandparents themselves (i.e., age and health status). Therefore, this research aims to study the roles of grandparents in 
supporting labor participation of mothers in Indonesia after controlling other related factors.

\section{LITERATURE RIVIEW}

Ref. [10] described a simple model linking labor supply to childcare, where childcare quality is assumed to be homogeneous (the child's outcome effect of child care is negligible), providing a useful starting point for analyzing demand on parenting. Mother is an agent in the model, making decisions about parenting for her children. Based on the model, [10] argued that a higher price of childcare tends to drive the net market wage is below the reservation wage; thus reducing the likelihood of mothers to work. In other words, according to Kimmel (1998) in [6], lower childcare costs result in higher female work participation. Ref. [10] also proposed that in some families who have access to parenting by a relative, there is no monetary cost in childcare. But, not all families use it, because of the opportunity cost: a leisure sacrifice or income that should be obtained as the consequences of providing care.

Further, Smith $(2000,2002)$ in [11] revealed that in the United States, in addressing the increased cost of formal childcare from time to time, many families then resort to surrendering childcare to the nearest relatives that usually do not cost money. Ref. [12] using NLSY79, found a significant positive correlation between maternal participation and having a grandmother living in the household. The results of [6] study using the Multiscopo-Famiglie e Soggetti Sociali (Families and Social Subjects) Survey 2003 data showed that having grandparents who assist in parenting improves the participation of the mothers in the labor force. The effect is stronger among uneducated mothers with young children living in the north and central Italy. Ref. [13] in their research indicated that in some countries (Europe), the mother's work participation is significantly related positively with the availability of grandparenting. In this case, the role of grandparents is an important element in the alignment of the role of a mother, between at work and in the family.

Ref. [6] emphasized that the provision of more child care services is not likely to be sufficient in an effort to increase the participation of the female workforce if it is not accompanied by perceived quality improvement, as parents face information asymmetry when using child care services (private or public as a provider). Ref. [14] found that low confidence in child care services reduces the tendency of mothers leaving their children, since parents do not trust the quality of child care services. When a mother decides to work, the grandparents' care for her child will always be an option.

Furthermore, [15] stated that there are factors influencing the work participation of mothers. First, the conditions that enable mothers to participate in the labor market, such as the number and age of the child. In many studies, the number and age of children can be obstacles for mothers to participate in the labor market [16], [17], [18]. Second, the conditions that support housewives to participate in the labor market (facilitating condition), such as the level of education and work experience. Based on previous studies, education is a driving force for mothers to enter the labor market [16], [17], [18]. Third, the precipitating condition of mothers to participate in the labor market, such as dissatisfaction with household income levels and self-actualizing desires. In various studies, household income levels that encourage mothers to enter the labor market can also be described in the form of income of other household members, household expenditures, per capita expenditures, and so on.

Furthermore, [18] explained that husband earnings influence mothers' work participation. When the income of the husband decreases, the tendency of a woman to enter the labor market is bigger. This opportunity will be even greater when it is associated with residential areas; in rural areas, the participation of mothers is higher than in urban areas where the wages of husbands are no longer sufficient for the needs of their families. This is because in rural areas there are many types of jobs that do not require high skills, so the opportunity for housewives to get a job is greater than in urban areas. Similarly, a research conducted by [16] used the working status variables of husbands; found that housewives tend to enter the labor market on conditions when the husband is not working.

Based on the theoretical framework and previous empirical studies described above, it is hypothesized that the presence of grandparent has a significant positive effect on mothers' participation in the labor force; even after controlling for mothers' educational attainment, the presence of children age 0-6 and 7-12 years, husbands' working status and place of residence.

\section{METHODOLOGY}

This study utilized the results of 2015 Intercensal Population Survey (SUPAS) which involved a large sample, spread across districts/cities in Indonesia. SUPAS 2015 provides data related to grand-parenting especially among the elderly. The unit of analysis in this study is a sample of women aged 15-54 years, who were married or living together, who lived with a husband/spouse, and who had children aged 0-12 years. The number of the women for the analysis was 295,436 .

Referring to the previous literature review, the dependent variable is the work participation of the women aged 15-54 years. The independent variables were divided into 2 (two), i.e. the causal factor, i.e. grand-parenting, and classification factors. The mother work participation was categorized into formal sector (0), informal sector (1) and not working (2). The presence of grand-parenting was classified into grandparent present, all healthy or quite healthy and all grand-parenting (1), grandparent present with other conditions (2), grandparent present and not grand-parenting (3) and no grandparent (4). Classification factors included mother's educational attainment (1=university, $2=$ secondary and 3 =primary or no education), the presence of children (1=had children age $0-6,2=$ had children age 0-6 and 7-12 and $3=$ had children age 7-12), husbands' working status $(1=$ formal sector, $2=$ informal sector 
and $3=$ not working) and place of residence ( $1=$ rural and $2=$ urban).

The data were analyzed descriptively and inferentially. Descriptively, univariate and bivariate analyses were conducted. Univariately, the percentage distribution of women in the study by background characteristics was given. Bivariately, the percentage distribution of labor participation of studied women by background characteristics was also provided. Inferentially, a multivariate analysis, employing a multinomial logistic regression, was carried out to study the effects of grand-parenting and classification factors on mothers' labor participation. The model is as follows:

$$
\begin{aligned}
& \ln \left(P_{0} / P_{2}\right)=g_{0}=\beta_{10}+\beta_{111} G_{-} \text {Parenting }_{1}+\beta_{112} G_{-} \text {Parenting }_{2} \\
& +\beta_{113} G_{-} \text {Parenting }_{3}+\beta_{121} \text { Educ_Mom } \text { Eom }_{1}+ \\
& \beta_{122} \text { Educ_Mom }_{2}+\beta_{131} \text { Child }_{1}+\beta_{132} \text { Child }_{2} \\
& +\beta_{141} \quad \text { Work_Husband } 1+\beta_{142} \\
& \text { Work_Husband } 2+\beta_{15} \text { Region }+\varepsilon_{0}
\end{aligned}
$$

$\ln \left(P_{1} / P_{2}\right)=g_{1}=\beta_{20}+\beta_{211} G_{-}$Parenting $_{1}+\beta_{212} G_{-}$Parenting $_{2}$ $+\beta_{213} G_{-}$Parenting $_{3}{ }^{*}+\beta_{221}$ Educ_Mom $1+$ $\beta_{222}$ Educ_Mom ${ }_{2}+\beta_{231}$ Child $_{1}+\beta_{232}$ Child $_{2}$ $+\beta_{241} \quad$ Work_Husband $1+\beta_{242}$ Work_Husband $_{2}+\beta_{25}$ Region $+\varepsilon_{1}$

where $P_{0}=$ probability of working in formal sector, $P_{1}=$ probability of working in informal sector and $P_{2}=$ probability of not working, $G_{-}$Parenting $_{k}=$ dummy variables for the presence of grand-parenting, Educ_Mom ${ }_{k}=$ dummy variables for mother's educational attainment, Child $_{k}=$ dummy variables for the presence of children, Work_Husband $k=$ dummy variables for husband's working status and Region $=$ dummy variable for the place of residence, $\beta_{i 0}=$ the intercepts and $\beta_{i j k}=$ the regression coefficients in the $i^{\text {th }}$ model for independent variable $j$ and category $k$.

\section{RESULT AND DISCUSSION}

The results of univariate analysis show that 13.5 percent of women aged 15-54 years who were married/living together and who lived with their spouses and had children aged 0-12 years lived with parents or parents-in-law, or so-called 'grandparents' for their children (Table 1). This indicates that extended family still exists in Indonesia. Of the 13.5 percent of mothers living with 'grandparents', 5.4 percent of them lived with healthy or quite healthy grandparents, all of whom were grand-parenting, and 5.3 percent of mothers lived with grandparents and all were not grand-parenting. In addition, the majority of the studied women had secondary education (graduated from junior high school or equivalent or senior high school/equivalent), followed by low education (no primary or elementary education certificates or equivalent). Less than ten percent of studied women had high education (completed Diploma I/ II/III/IV or Strata 1/2/3). Further, most of studied women had children aged 0-6 years, had husbands who worked in the informal sector and lived in rural areas.
Lastly, almost 44 percent of the studied women were working

\begin{tabular}{|c|c|}
\hline Backgorund Characteristics & Percentage \\
\hline \multicolumn{2}{|l|}{ Grand-parenting } \\
\hline $\begin{array}{l}\text { Grandparent present, all healthy or } \\
\text { quite healthy and all grand-parenting }\end{array}$ & 5.4 \\
\hline $\begin{array}{r}\text { Grandparent present with other } \\
\text { conditions }\end{array}$ & 2.9 \\
\hline $\begin{array}{r}\text { Grandparent present and not grand- } \\
\text { parenting }\end{array}$ & 5.3 \\
\hline No grandparent & 86.5 \\
\hline \multicolumn{2}{|l|}{ Mother's educational attainment } \\
\hline High & 9.8 \\
\hline Secondary & 49.7 \\
\hline Low & 40.5 \\
\hline \multicolumn{2}{|l|}{ Presence of children } \\
\hline Age $0-6$ & 39.2 \\
\hline Age $0-6$ and 7-12 & 28.1 \\
\hline Age 7-12 & 32.6 \\
\hline \multicolumn{2}{|l|}{ Husband's working status } \\
\hline Formal sector & 40.9 \\
\hline Informal sector & 55.8 \\
\hline Not working & 3.3 \\
\hline \multicolumn{2}{|l|}{ Place of residence } \\
\hline Urban & 40.6 \\
\hline Rural & 59.4 \\
\hline \multicolumn{2}{|l|}{ Mother's working status } \\
\hline Formal sector & 14.3 \\
\hline Informal sector & 29.6 \\
\hline Not working & 56.1 \\
\hline Total & $100.0(295,436)$ \\
\hline
\end{tabular}
mothers, 14.3 percent in the formal sector and 29.6 percent in the informal sector.

TABLE 1. Percentage Distribution Of Studied Women By BACKGROUND CHARACTERISTICS: INDONESIA SUPAS 2015

The results of bivariate analysis indicate that the percentage of the studied women who worked in the formal sector is the highest among those who had parents/parents-in-law who were all healthy or quite healthy to fully take care of their children in the form of grand-parenting, among those who had high education, among those who had children age 0-6 years, among those who had husband working in the formal sector and among those who lived in urban areas (Table 2). Meanwhile, the percentage of mothers who worked in the informal sector is the highest among those who had no grand-parenting, among those who had low education, among those who had children age 7-12 years, among those with husband working also in the informal sector and among those who lived in rural areas. These results support the conclusion of [1] stating that the characteristics of formal employment with a fixed working schedule with minimum working hours; and the difference in adjustment of household responsibilities between a mother and a husband remains an obstacle for mothers to take part in the formal sector when linked to the child care role. Meanwhile, the informal sector that promises flexibility of place and time for mothers, remains an option in the mother's participation in the labor market. 
TABLE 2. Percentage Distribution Of Working Status Of Studied WOMEN BY BACKGROUND CHARACTERISTICS:INDONESIA SUPAS 2015

\begin{tabular}{|c|c|c|c|c|}
\hline \multirow{2}{*}{$\begin{array}{c}\text { Backgorund } \\
\text { Characteristics }\end{array}$} & \multicolumn{3}{|c|}{ Working Status } & \multirow{2}{*}{$\begin{array}{c}\text { Total } \\
(n)\end{array}$} \\
\hline & Formal & Informal & $\begin{array}{c}\text { Not } \\
\text { working }\end{array}$ & \\
\hline \multicolumn{5}{|l|}{ Grand-parenting } \\
\hline $\begin{array}{r}\text { Grandparent } \\
\text { present, all } \\
\text { healthy or quite } \\
\text { healthy and all } \\
\text { grand-parenting }\end{array}$ & 23.3 & 23.5 & 53.2 & $\begin{array}{r}100.0 \\
(15,875)\end{array}$ \\
\hline $\begin{array}{r}\text { Grandparent } \\
\text { present with other } \\
\text { conditions } \\
\end{array}$ & 17.7 & 28.0 & 54.3 & $\begin{array}{r}100.0 \\
(8,507)\end{array}$ \\
\hline $\begin{array}{r}\text { Grandparent } \\
\text { present and not } \\
\text { grand-parenting }\end{array}$ & 15.0 & 30.1 & 54.8 & $\begin{array}{r}100.0 \\
(15,515)\end{array}$ \\
\hline No grandparent & 13.6 & 30.0 & 56.4 & $\begin{array}{r}100.0 \\
(255,539) \\
\end{array}$ \\
\hline \multicolumn{5}{|c|}{ Mother's educational attainment } \\
\hline High & 63.0 & 8.6 & 28.4 & $\begin{array}{r}100.0 \\
(28,895) \\
\end{array}$ \\
\hline Secondary & 11.8 & 25.4 & 62.8 & $\begin{array}{r}100.0 \\
(146,818) \\
\end{array}$ \\
\hline Low & 5.7 & 39.8 & 54.5 & $\begin{array}{r}100.0 \\
(119,723) \\
\end{array}$ \\
\hline \multicolumn{5}{|l|}{ Presence of children } \\
\hline Age $0-6$ & 15.6 & 22.4 & 62.0 & $\begin{array}{r}100.0 \\
(115,887) \\
\end{array}$ \\
\hline Age $0-6$ and $7-12$ & 12.1 & 31.0 & 56.9 & $\begin{array}{r}100.0 \\
(83,121) \\
\end{array}$ \\
\hline Age $7-12$ & 14.7 & 36.9 & 48.4 & $\begin{array}{r}100.0 \\
(96,428) \\
\end{array}$ \\
\hline \multicolumn{5}{|c|}{ Husband's working status } \\
\hline Formal sector & 24.4 & 13.8 & 61.8 & $\begin{array}{r}100.0 \\
(120,859) \\
\end{array}$ \\
\hline Informal sector & 6.8 & 41.6 & 51.6 & $\begin{array}{r}100.0 \\
(164,816) \\
\end{array}$ \\
\hline Not working & 16.7 & 21.2 & 62.1 & $\begin{array}{r}100.0 \\
(9,761) \\
\end{array}$ \\
\hline \multicolumn{5}{|l|}{ Place of residence } \\
\hline Urban & 21.5 & 17.9 & 60.5 & $\begin{array}{r}100.0 \\
(119,846) \\
\end{array}$ \\
\hline Rural & 9.4 & 37.5 & 53.1 & $\begin{array}{r}100.0 \\
(175,590) \\
\end{array}$ \\
\hline Total & 14.3 & 29.4 & 56.1 & $\begin{array}{r}100.0 \\
(295,436)\end{array}$ \\
\hline
\end{tabular}

The results of multivariate analysis confirm that grandparenting statistically and significantly influences mother's work participation, even after controlling the effects of her educational attainment, the presence of young children, her husband's work participation and her place of residence. Mothers aged 15-54 years who were in union, lived with their spouses and had children aged 0-12 years old who had grandparenting and all healthy or well enough, who had "grandparents" with other conditions and who had "grandparents" without grand-parenting, respectively, 1.45 times, 1.32 times and 1.09 times more likely to work in the formal sector than not working compared to other mothers without "grandparents."

So, it can be said that mothers tend to work formally than not working, when grandparents are with her. The tendency is increasing as grandparents participate in helping to nurture their children in the form of grand-parenting' and for that the grandparents still have to be healthy or at least healthy enough so as not to interfere with their daily activities. This is in line with [8] and [9] who emphasized the importance of considering the characteristics of grandparents themselves including their age and health status in their involvement in grand-parenting. While it is related to the condition even though grandparents exist and none of the grand-parenting still positively influences the possibility of formal working mother versus not working. This indicates that the presence of grandparents at home can answer the worries of information asymmetry facing parents when using child care services, whether private or public as providers [6], so that mothers feel safe when leaving their children to work.

Mothers aged 15-54 years who were in union, lived with their spouses and had children aged 0-12 years old with secondary and high education, respectively, 1.58 times and 17 times more likely to work in the formal sector than not working compared to those with low education. The results support the findings by [4] and [5] stating that mothers with the highest educational attainment had the highest formal sector job opportunities.

Mothers aged 15-54 years who were in union, lived with their spouses and had children age 0-12 years old who had children age 0-6 years and 7-12 years and who only had children age 0-6 years, respectively, 0.61 times and 0.63 times less likely to work in the formal sector than not working compared to those who had children age 7-12 year olds. These results confirm the findings by [5] reporting that the presence of young children reduced the possibility of a woman participates in a formal (paid) job. Young children need more intensive attention and special care, so mothers tend to get out of the job market to take care of their young children.

Mothers aged 15-54 years who were in union, lived with their spouses and had children age 0-12 years old whose husbands in the formal sector and whose husbands working in the informal sector, respectively, 1.15 times and 0.58 times more likely to work in the formal sector than not working compared to mothers with unemployed husbands. Meanwhile, the studied women who lived in urban areas 1.18 times more likely to work in the formal sector than not working compared with those living in rural areas. This can be influenced by the different types of work in rural areas and in urban areas [4]. In general, more urban occupations require high skills and tend to make housewives work outside the house. Such conditions require a mother's ability to harmonize between parenting and participate in the labor market if the person decides to work [6].

TABLE 3. PARAMETER ESTIMATE (Estimate), SignifiCANCE (Sig) AND ODDS RATIO (OR) OF MULTINOMIAL LOGISTIC REGRESSION MODEL FOR THE EFFECTS OF GRAND-PARENTING ON MOTHER'S WORK PARTICIPATION: INDONESIA SUPAS 2015

\begin{tabular}{|l|c|c|c|c|c|c|}
\hline \multirow{2}{*}{ Covariate } & \multicolumn{3}{|c|}{ Formal vs Not working } & \multicolumn{3}{c|}{ Informal vs Not working } \\
\cline { 2 - 7 } & Estimate & Sig & OR & Estimate & Sig & OR \\
\hline Intercept & -1.808 & 0.000 & & -0.393 & 0.000 & \\
\hline
\end{tabular}




\begin{tabular}{|c|c|c|c|c|c|c|}
\hline \multicolumn{7}{|c|}{ Grand-parenting } \\
\hline $\begin{array}{r}\text { Grandparent } \\
\text { present, all } \\
\text { healthy or } \\
\text { quite healthy } \\
\text { and all } \\
\text { grand- } \\
\text { parenting }\end{array}$ & 0.372 & 0.000 & 1.45 & 0.027 & 0.211 & 1.03 \\
\hline $\begin{array}{r}\text { Grandparent } \\
\text { present with } \\
\text { other } \\
\text { conditions }\end{array}$ & 0.279 & 0.000 & 1.32 & 0.061 & 0.023 & 1.06 \\
\hline $\begin{array}{r}\text { Grandparent } \\
\text { present and } \\
\text { not grand- } \\
\text { parenting }\end{array}$ & 0.088 & 0.001 & 1.09 & 0.036 & 0.072 & 1.04 \\
\hline $\begin{array}{r}\text { No } \\
\text { grandparent }{ }^{\circledR} \\
\end{array}$ & - & - & - & - & - & - \\
\hline \multicolumn{7}{|c|}{ Mother's educational attainment } \\
\hline High & 2.833 & 0.000 & 17.0 & -0.245 & 0.000 & 0.78 \\
\hline Secondary & 0.456 & 0.000 & 1.58 & -0.237 & 0.000 & 0.79 \\
\hline Low $\AA$ & - & - & - & - & - & - \\
\hline \multicolumn{7}{|c|}{ Presence of children } \\
\hline Age $0-6$ & -0.464 & 0.000 & 0.63 & -0.692 & 0.000 & 0.50 \\
\hline $\begin{array}{r}\text { Age } 0-6 \text { and } \\
7-12\end{array}$ & -0.496 & 0.000 & 0.61 & -0.334 & 0.000 & 0.72 \\
\hline Age 7-12® & - & - & - & - & - & - \\
\hline \multicolumn{7}{|c|}{ Husband's working status } \\
\hline Formal sector & 0.135 & 0.000 & 1.15 & -0.302 & 0.000 & 0.74 \\
\hline $\begin{array}{r}\text { Informal } \\
\text { sector }\end{array}$ & -0.545 & 0.000 & 0.58 & 0.790 & 0.000 & 2.16 \\
\hline $\begin{array}{r}\text { Not } \\
\text { working } @ \\
\end{array}$ & - & - & - & - & - & - \\
\hline \multicolumn{7}{|c|}{ Place of residence } \\
\hline Urban & 0.164 & 0.000 & 1.18 & -0.561 & 0.000 & 0.57 \\
\hline Rural® & - & - & - & - & - & - \\
\hline
\end{tabular}

Mothers aged 15-54 years who were in union, lived with their spouses and had children aged 0-12 years old who had grand-parenting and all healthy or well enough, who had "grandparents" with other conditions and who had "grandparents" without grand-parenting, respectively, 1.03 times, 1.06 times and 1.04 times more likely to work in the informal sector than not working compared to mothers with no grandparents. As in the formal sector, it can be said that mothers tend to work informally rather than not working when grandparents are with her, both when grandparents are all healthy or well enough and participating in the care of their children with grand-parenting and grandparents are there and all are not grand-parenting.

Mothers aged 15-54 years who were in union, lived with their spouses and had children aged 0-12 years old and had secondary and high education, respectively, 0.79 times and 0.78 times less likely to work in the informal sector than not working compared to mothers with low education. These results show that most marginalized women working in the informal sector are those with the lowest education and the lowest earning potential [5].

Mothers aged 15-54 years who were in union, lived with their spouses and had children aged 0-12 years old who had children age 0-6 years and 7-12 years and who only had children age $0-6$ years, respectively, 0.50 times and 0.72 times less likely to work in the informal sector than not working compared to those who had children age 7-12 year olds.

Mothers aged 15-54 years who were in union, lived with their spouses and had children age 0-12 years old whose husbands in the formal sector and whose husbands working in the informal sector, respectively, 0.74 times less likely and 2.16 times more likely to work in the informal sector than not working compared to mothers with unemployed husbands. This is relevant with Posadas and Smitz research results in [1] explaining that in Indonesia, women whose husbands are unemployed significantly have more possibility to be unpaid workers than those whose husbands are wage workers. Meanwhile, the studied women who lived in urban areas 0.57 times less likely to work in the informal sector than not working compared to those living in rural areas.

\section{CONCLUSION}

The presence of grandparents in the house increases the chance of mothers with young children to participate in the labor market, both in the formal and informal sectors. The probability of participating in the formal sector is greater when grandparents are all healthy or healthy enough and grandparenting. The opportunities of participating in the informal sector is greater when grandparents are in other conditions. These findings indicate that the labor participation of Indonesian women, especially those with young children, can increase by involving grandparents in grand-parenting in order to improve Indonesia's competitiveness, boost economic growth and reap the demographic dividend.

\section{REFERENCES}

[1] World Bank. 2012. Gender Equality and Development. World Development Report 2012. World Bank. (C) World Bank. https://openknowledge.worldbank.org/handle/10986/4391 License: CC BY 3.0 IGO.”.

[2] Badan Pusat Statistik. (2014). Indeks Pembangunan Gender 2014. Jakarta: Badan Pusat Statistik. https://bps.go.id/website/pdf_publikasi/Indeks-Pembangunan-Gender2014_rev.pdf (accessed February 21, 2017).

[3] Becker, Gary S. (1976). The Economic Approach to Human Behaviour, The University of Chicago Press.

[4] Adioetomo, Sri Moertiningsih, \& Eggleston, E. (1998). 'Helping the Husband, Maintaining Harmony: Family Planning, Women's Work and Women's Household Autonomy in Indonesia'. Journal of Population, Vol. 16, No. 3.

[5] Gallaway, Julie H., \& Bernasek, Alexandra. (2002). Gender and Informal Sector Employment in Indonesia. Journal of Economic Issues, 36(2), 313-321. Retrieved from http://remotelib.ui.ac.id:2059/stable/4227780

[6] Arpino, B., Pronzato, C. D., \& Tavares, L. P. (2014). 'The effect of grandparental support on mothers' labour market participation: an instrumental variable approach'. European Journal of Population, 30(4), 369-390.

[7] Presser, Harriet B. "Some Economic Complexities of Child Care Provided by Grandmothers." Journal of Marriage and Family 51, no. 3 (1989): 581-91. doi:10.2307/352158. 
[8] Gray, A. (2005). 'The changing availability of grandparents as carers and its implications for childcare policy in the UK'. Journal of Social Policy 34(4): 557-577. doi:10.1017/S0047279405009153.

[9] Hank, K. 'Proximity and Contacts between Older Parents and Their Children: A European Comparison.' Journal of Marriage and Family 69, no. 1 (2007): 157-73. lib.ui.ac.id:2059/stable/4622423.

[10] Blau, D., \& Currie, J. (2006). 'Preschool, day care, and after school care: Who's minding the kids?', vol. 2, Chapter 20. In E. A. Hanushek \& F. Welch (Eds.), Handbook on the economics of education. Amsterdam: North Holland Press.

[11] Posadas, Josefina, and Marian Vidal-Fernández. "Grandparents' childcare and female labor force participation." IZA Journal of Labor Policy 2.1 (2013): 1.

[12] Leibowitz, A., Klerman, J., \& Waite, L. (1992). 'Employment of New Mothers and Child Care Choice: Differences by Children's Age'. The Journal of Human Resources, 27(1), 112-133. doi:10.2307/145914

[13] Aassve, A., Arpino, B., \& Goisis, A. (2012). 'Grandparenting and mothers' labour force participation: A comparative analysis using the generations and gender survey'. Demographic Research, 27, 53.
[14] El-Attar, M. (2013). 'Trust, child care technology choice and female labor force participation'. Review of Economics of the Household, 11(4), 507-544.

[15] Sobol, Marion G. (1963). Commitment to Work. The Employed Mother in America. Francis Ivan Nye \& Lois Wladis Hoffman (Ed.). Chicago : Rand McNally \& Co. http://books.google.co.id/books?id=NNRnV6uPZz8C

[16] Spencer, Byron G. (1973). Determinants of the Labour Force Participation of Married Women : A Micro-Study of Toronto Households. The Canadian Journal of Economics Vol. 6, No. 2 (May, 1973), pp. 222-238. Blackwell Publishing and Canadian Economics Association. http://www.jstor.org/stable/134192

[17] Phimister, Euan, \& Esperanza Vera-Toscano, \& Alfons Weersink. (2002). Female Participation and Labor Market Attachment in Rural Canada. American Journal of Agricultural Economics, Vol. 84, No. 1 (Feb., 2002), pp. 210- 221. Blackwell Publishing and Agricultural \& Applied Economics Association. http://www.jstor.org/stable/1245034

[18] Asiati, Devi. (2004). 'Penawaran Tenaga Kerja Perempuan Kawin di Indonesia (Analisis Data Susenas 2002)'. Tesis Pasca Sarjana Kajian Kependudukan dan Sumber Daya Manusia. Depok: Universitas Indonesia. 